\title{
Do Climate Changes Lead to Income Inequality? Empirical Study on the Farming Community in Malaysia
}

\author{
Md. Mahmudul Alam* \\ Senior Lecturer \\ School of Economics, Finance \& Banking \\ College of Business \\ Universiti Utara Malaysia \\ 06010 UUM Sintok, Kedah, Malaysia \\ E-mail: rony000@gmail.com \\ Khan Md. Raziuddin Taufique \\ $\mathrm{PhD}$ Student \\ Institute for Environment and Development \\ National University of Malaysia \\ Bangi, Selangor, Malaysia \\ Email: kmrtaufiq@gmail.com \\ Azizullah Sayal \\ Assistant Professor \\ Department of Management Sciences \\ Comsats Institute of Information Technology \\ Abbottabad, Pakistan \\ Email: sayal@ ciit.net.pk \\ * Corresponding author
}

\section{Citation Reference:}

Alam, M.M., Taufique, K., and Sayal, A. 2017. Do Climate Changes Lead to Income Inequality? Empirical Study on the Farming Community in Malaysia, International Journal of Environment and Sustainable Development, Vol. 16(1), pp. 43-59. (online) http://www.inderscienceonline.com/doi/abs/10.1504/IJESD.2017.080848

This is a pre-publication copy.

The published article is copyrighted by the publisher of the journal. 


\title{
Do Climate Changes Lead to Income Inequality? Empirical Study on the Farming Community in Malaysia
}

\begin{abstract}
Changes in climatic factors have different impacts on different social groups. But the farmers are considered to be the most vulnerable group because of their direct and indirect dependency on climatic factors. This study aims to understand the nature of socioeconomic impacts of climatic changes on the farmers in Malaysia. A questionnaire survey was conducted on a sample of 198 paddy farmers in the Integrated Agricultural Development Area at North-West Selangor of Malaysia in 2009. Data were analyzed using descriptive statistics, ordinal scale and percentile. The study reveals that climatic changes have adverse impacts on agricultural productivity, profitability, income equality, employment, farmer's health, and government subsidy policy. The Kuznets ratio and Gini coefficient indicate that there is highly unequal distribution of income. Climatic changes are contributing to the widening of this income gap, because poor farmers are affected more by the adverse effects of climatic changes. The current government subsidy policy is not found appropriate and adequate to support and encourage the farmers to adequately adapt to the climatic changes and to reduce the inequality among the farming community. The paper ends up with recommending some policy guidelines to counter adverse effects of climate change on income of paddy farmers in Malaysia.
\end{abstract}

Key words: climatic change; income equality; Gini coefficient; Kuznets ratio; Lorenz curve; poverty; agriculture; paddy; Malaysia

Corresponding Author's Email: rony000@ gmail.com

\section{INTRODUCTION}

Climate is expressed and described by the factors like the amount of rainfall, sunshine hours, temperature, relative humidity and length of flood or drought periods. The impacts of climate change are not limited to any geographical boundary or timeframe. Some of the aspects are long term and related to national or international security such as, soil erosion, chemical poisoning or nuclear waste (Daly and Cobb 1990), and some issues are related to daily quality of life such as water pollution, shortage of food or resources (Homer-Dixon 1992). Climate change, therefore, affects various areas, sectors and stakeholders in various ways (Klein et al. 2005; Siwar 2009).

Since agriculture is heavily dependent on climatic conditions, changes in the climatic factors result in year-to-year and area-to-area variability of crop production which largely affects the social and economic sustainability of the farmers. Several variables influence climate change that, in turn, leads to changes in the variables of agricultural sustainability and their impacts on the agricultural system and socioeconomic characteristics of the farmers. Due to the changes in climate factors, the factors relevant to agricultural sustainability, such as volume/yield, area and value of production, also change. Vulnerable agricultural sustainability may result in inconsistency in total production quantity, profit margin of crops, profit margin of final goods, profit margin of production and import, farm and off-farm wage rate and so on. 
Accordingly the adverse climatic change leads to decline in farmers' income which is likely to trigger poverty. Moreover, climate change causes frequent natural disasters and consequently fulltime farmers become unemployed in a major time of the year. The unexpected behavior of climate factors may also cause disease, disability, frequent sickness and other health hazards to the farmers which, in turn, lead to long unemployment periods. Overall, climate change influences the agricultural sustainability negatively in Malaysia; as a consequence people who are dependent on agriculture are more vulnerable in terms of socioeconomic perspective than other social groups in Malaysia (Alam et al. 2010b). Even within the farming community, climatic changes are contributing to the widening of this income gap, because poor farmers are affected more by the adverse effects of climatic changes (Alam et al. 2011).

Impacts of climate change on agriculture vary from period to period, from area to area and from country to country based on economic, social, political, and environmental condition of the locality. Like other countries in this region, climate change has adversely affected agriculture in a variety of ways in different parts of Malaysia. Its fisheries, forestry and livestock and crop cultivations have been seriously affected by the climate change. This empirical paper investigates the direct impacts of climate change on farmers and analyses the nature and magnitude of socio-economic impacts of the climate change on farmers, especially the issue of inequality among the farming community in Malaysia.

\section{DATA AND METHODOLOGY}

This study relies on primary data from a research project entitled "the economics of climate change: economic dimensions of climate change, impacts and adaptation practices in agriculture sector: case of paddy sector in Malaysia", conducted by the Institute for Environment and Development (LESTARI) of the National University of Malaysia (UKM) funded by Ministry of Science, Technology and Environment of the Government of Malaysia (Alam et al. 2010a). Data were collected through a sample survey of paddy producing farmers in the eight sections of the Integrated Agricultural Development Area (IADA) of North-West Selangor, Malaysia. Total paddy irrigated area is 18,980 ha, with the additional 625 ha being used for drainage. There are a total of 10,300 paddy farmers and 30,000 other crops producers. The total size of the agricultural community is 50,000.

The target group of the survey was paddy producing farmers. The survey was conducted by regular enumerators of the IADA authority using a structured questionnaire under the direct supervision of IADA officials. A total of 198 respondents were selected using stratified random sampling based on the size of the irrigated land area and locality. Details of socioeconomic profiles of the respondents are available at Alam et al. (2010a). Finally, the study uses the descriptive statistics, percentile and scale analysis to assess other factors of socioeconomic sustainability and adaptability of farmers to climate change.

\section{IMPACT OF CLIMATE CHANGE ON AGRICULTURE IN MALAYSIA}

The temperature in Malaysia is projected to rise by $0.3^{\circ} \mathrm{C}$ to $4.5^{\circ} \mathrm{C}$ due to high greenhouse gas emissions the temperature. Warmer temperature will cause sea level to rise about $95 \mathrm{~cm}$ over a hundred year-period. The changes in rainfall may fluctuate from about $-30 \%$ to $+30 \%$ (NRS 2001). This change is projected to reduce crop yield and cause drought in many areas and cultivation of some crops such as rubber, oil palm and cocoa may not be any more possible. 
Another projection shows that maximum monthly precipitation will increase up to $51 \%$ in the states of Pahang, Kelantan and Terengganu, while the minimum precipitation will decrease ranging from $32 \%$ to $61 \%$ all over Peninsular Malaysia (NAHRIM 2006). However, the annual rainfall will increase up to $10 \%$ in Kelantan, Terengganu, Pahang and North West Coast, and decrease up to 5\% in Selangor and Johor. This variation of climatic factors will make the agricultural system vulnerable.

Temperature above $25^{\circ} \mathrm{C}$ may cause decline in grain mass and grain yield (Tashiro and Wardlaw 1989; Baker and Allen 1993). The average temperature in rice growing areas of Malaysia is about $26^{\circ} \mathrm{C}$. The actual farm yield of paddy in Malaysia varies from 3-5 tons per hectare as against the potential yield of 7.2 tons (Singh et al. 1996). Singh et al. (1996) also mentioned that a decline of rice yield between $4.6 \%-6.1 \%$ per $1{ }^{\circ} \mathrm{C}$ temperature increase under the present $\mathrm{CO}_{2}$ level. A study found that a $1 \%$ increase in temperature leads to $3.44 \%$ decrease in current paddy yield, and $.03 \%$ decrease in paddy yield in next season and a $1 \%$ increase in rainfall leads to $.12 \%$ decrease in current paddy yield, and $.21 \%$ decrease of paddy yield in next season (Alam et al. 2014).

Tisdell (1996) reports that rainfall variability increases the level of environmental stress that affects the capability of the system to maintain productivity. Projection (NRS 2001) shows that given the $\mathrm{CO}_{2}(\mathrm{ppm})$ as 400 and variation in temperature as $0.3^{\circ} \mathrm{C}$ and above, variation of rainfall by more than $0.4 \%$ by the year of 2020 will cause reduction in paddy production and earnings of farmers (Table 1). Total yearly rainfall in Malaysia is increasing and its monthly variation is too high (Alam et al. 2010a). The effect of lower rainfall can be checked through proper irrigation system, but the opposite phenomenon of over rainfall for any particular time, especially at the end of the crop cycle or at the maturity period that causes serious damages to crops, is absolutely uncontrollable.

\section{Insert Table 1 about here}

Total yearly rainfall in Malaysia is increasing but its monthly variation is too high. The most vulnerable states in terms of fluctuation in rainfall and temperature are Sabah, Terengganu, Kelantan, Sarawak, Kedah, Perlis, and Perak (NAHRIM 2006). The effect of lower rainfall can be somehow controlled through introduction of proper irrigation system. But the problem of over rainfall at any particular time is not controllable. Excess rainfall especially at the end of the crop cycle or at the maturity period, causes serious damages to crops. The most vulnerable group of people are the poor and hard-core poor engaged in agricultural activities and having relatively larger number of household members (NRS 2001). Since these farmers are dependent on agriculture, their family income declines with the decline in agricultural productivity and production. Change in climatic factors, therefore, affect directly and indirectly the social and economic sustainability of the farmers. Climatic changes cause crop damages leading to low productivity and high production cost, income losses to farmers, increase in seasonal unemployment rate, and increase in poverty level.

Upon realization of this problem, the Second National Agricultural Policy (1992-1997) was revised in 1998 and the Third National Agricultural Policy (1998-2010) was designed based on a vision of development of a dynamic agricultural sector focusing on an efficient marketled competitive growth. The principal aim of the Third National Agricultural Policy (19982010) is to maximize income of the stakeholders through optimal utilization of resources.

\section{NATURE AND INTENSITY OF INEQUALITY AMONG FARMERS}




\section{Difference in Social Characteristics}

\section{Demography}

According to the records of IADA, the distribution of ethnic groups among the farming community is 65 percent Malay, 22 percent Chinese and 13 percent Indian, whereas the survey covered distribution for this study is 89.9 percent Malay and 10.1 percent Chinese. There are few strong reasons behind this asymmetrical distribution of sample with respect to race. The survey is clustered based on area rather than ethnicity. Within a geographical location, the survey is conducted randomly, but geographically in most cases the same race groups stay together and their localized distributions are not same at all. In terms of gender, the distribution of sample is $9.6 \%$ females and $90.4 \%$ males. Among the Chinese group only male farmers are available in the survey and among the Malay group the proportion of female farmers is almost the same for all locations. The average age of all farmers is 52.9 years where that of males is 52.9 years and that of females is 53.5 years old. Among the female farmers, minimum age is 25 years and maximum is 75 years old. Among the male farmers, minimum age is 27 years and maximum is 84 years old. In total, only $8.5 \%$ farmers are below 40 years old, $18.2 \%$ are above 60 years old and rest $62.1 \%$ is between 40 to 60 years old. Most of the farmers have basic primary education (47.5\%) followed by secondary education (42.9\%). Only $4 \%$ farmers have tertiary education and $3.5 \%$ have no education. $93 \%$ of the total respondents are married where 3\% are unmarried. Among the women farmers, $42.1 \%$ are widows. The study reports that $29.3 \%$ of the families have three members, $52 \%$ have four to six members and $18.7 \%$ have more than six members in each family.

\section{Earning Family Members}

Among the household of farming community, 89.9 percent have only one earning member, 8.6 percent have two earning members, and 1.5 percent have three and above earning family members. Among 89.9 percent households having only one earning family member, 91.2 percent have no other activities except agricultural activities.

\section{Earnings Ratio and Dependency Ratio}

At the household level, the earning family members to total family members ratio is 0.294 , indicating only 29.4 percent of family members are engaged in economic activities. However, at household level, dependent family members to earning family members ratio is 3.52 , meaning one earning person needs to bear expenses of other 3.52 persons, and total 4.52 persons including himself. It also means that the burden rate for each earning member is 352 percent. The dependency ratio highly varies among households (standard deviation is 2.09). The range of this dependency ratio is minimum 0 to maximum 11 times.

\section{Occupation}

Agriculture is the main occupation of 88.4 percent and supplementary occupation of 8.6 percent heads of household in farmers' community. In addition, agriculture is the main occupation of 3.5 percent and supplementary occupation of 1 percent spouse of household heads in farmers' community. At the household level, 80.3 percent households have no other occupation except farming, which means 80.3 percent farming households are fully dependent on agriculture.

\section{Differences in Physical Assets}

\section{Home Ownership}


Among the farming community, 99 percent of the farmers have their own residences. This means farmers are stable in terms of having permanent address and staying place.

\section{Types and Status of Residence}

In total, 29.8 percent of farmers' houses are made of brick, 48 percent are made of both brick and wood, and 22.2 percent are made of wood. Among the Chinese farmers, 45 percent have brick made houses, 30 percent have brick and wood mixed houses, and 25 percent have wood made houses. Among the Malay farmers, 28 percent have brick made houses, 53.3 percent have mixed houses, and 22.2 percent have wood made houses. Most of the Chinese houses are made of brick, and most of the Malay houses are made of both brick and wood. So, Chinese farmers are comparatively richer than Malay farmers.

\section{Availability of Vehicle}

Farmers have several types of vehicles available at household level,. Among the household vehicles, 99 percent have motorcycle, 67.2 percent have car, 49.5 percent have bicycle and 12.1 percent have lorry or van. Among all farmers, 56 percent of total households have one car and 11 percent have two or more cars. A total of 38.9 percent households have one motorcycle and 60.1 percent have two or more. A total of 27.3 percent of the households have one bicycle and 22.2 percent have two or more. Only 9.6 percent households have one lorry/ van and 2.5 percent have two or more. Overall, all households of the farmer have minimum one vehicle.

\section{Ownership of Agricultural Land}

Among the farmers, 53 percent cultivate their own land only (traditional owners), 16.7 percent cultivate on rented land only (enterprises), and 30.3 percent cultivate both own and rented land (mixture of both). Among the own land cultivating farmers, the size of farm below 1 hectare is 11.4 percent, that between 1 to 3 hectares is 75.2 percent, and 3 or above is 13.3 percent. Among the farmers who cultivate on rented lands, the size of farm of 1 to 3 hectares is 54.5 percent and 3 or above is 45.5 percent. Among the farmers who cultivate paddy on both rented and own land, 36.7 percent of farms' size is below 1 hectares, 33.3 percent is 1 to 3 hectares and 30 percent is 3 hectares or above.

\section{Size of Paddy Farm}

The size of 17.2 percent of the farms is below 1 hectare, 59.1 percent is between 1-3 hectares, 12.1 percent is between 3-5 hectares and 11.6 percent is 5 hectares or above. So, commercial farms are increasing more in terms of small farmers.

\section{Availability of Machineries}

Among the farmers, 7.1 percent have heavy tractors, 6.1 percent have light, 57.6 percent have power sprayers, 48 percent have motorized blower water pumps, 57.6 percent have lawnmowers and 54.4 percent have poison sprayers. A total 6.6 percent of the farmers have none of these machineries, 23.7 percent have only one type of machinery, 26.3 percent have any two types of machineries, 24.2 percent have any three types of machineries, and 19.2 percent have more than three types of machineries. It indicates that farmers are transforming to machine oriented farming from labour oriented farming.

\section{Disparity in Income}

Small farmers are the major losers due to climate changes. Large-scale farmers get more benefits through economies of scale, marginally more benefit for high yield, and high 
productivity incentives from government. The subsidies for urea and compound have been continuing since 1979. The incentive for land preparation and organic fertilizer has been continuing since 2007. Providing compound and urea fertilizer, and pesticide incentive was introduced in 2008 and is still continuing. However, unless the adverse effects of climatic change are not reduced or removed and productivity is increased, government support and subsidy cannot produce a sustainable and progressive paddy sector, in particular, and the agriculture in general.

The degree of inequality is measured by Inequality Ratio, also known as Kuznets ratio. The ratio measures inequality through the ratio of income of top $20 \%$ to income of bottom $40 \%$. Here, the ratio is 2.88 , meaning that the degree of agricultural inequality at household level is nearly three times. If the value was calculated on population level instead of household level, the ratio would be more due to more population in the poorer households and less population in richer households.

\section{Insert Figure 1 about here}

Another measure of inequality is Gini coefficient. The coefficient ranges from 0 to 1 , where 1 indicates perfect inequality and 0 means perfect equality. Based on the Lorenz Curve, which is a graphical representation of the income/wealth vs. population distribution function, the Gini coefficient in the agricultural sector of Malaysia is 0.443 (Figure 1) indicating quite high degree of inequality in the agricultural community.

\section{CLIMATE CHANGE LEADING CHANGES IN INCOME EQUALITY}

\section{Changes in Crops' Productivity}

The yields of paddy in main season and off-season are close, with very little fluctuation. The yield (per hectare) of $13.6 \%$ of the farmers is below 5 tons, $58.5 \%$ of the farmers is $5-8$ tons, and $27.8 \%$ of the farmers is 8 tons or above. Average yield of Chinese is far better than Malays. The average yield per hectare of Chinese is 10.09 tons where Malays is 6.47 tons, and total is 6.85 tons. The yields of Sekinchan area, where most farmers are Chinese, are very high in respect to yield of other locality because of high productivity and farm management of Chinese ethnic group.

The target of IADA is 7.5 ton paddy per hectare. But the actual average yield is 6.85 ton per hectare has been found by the survey. Moreover, 64.6 percent of farmers and 50 percent of paddy cultivated areas are below the target level. According to the statistics, paddy yield in the IADA, West Selangor area is 5.042 ton in 2007 that decreases to 4.819 ton in 2008 (Agriculture Statistical Handbook 2008).

\section{Changes in Agricultural Income}

According to farmers, $68.2 \%$ agree that paddy production is not profitable enough due to low productivity. Beside this, $67.2 \%$ farmers say paddy production is still better than other crops production because of huge subsidy and incentives. In Malaysia, government provides several incentives to farmers to increase productivity. Among the incentives, input subsidy, irrigation facility and land preparation incentives are proportionately distributed among the farmers. But few subsidy and incentive programs also lead to inequality. For example, government provides selling price subsidy RM 248.1 per ton, and yield increasing incentives 
RM 650 per ton if farmer can produce 10ton or above per ha. The farmers who can produce 10 ton or above has already a higher income than other low productive farmers. As a consequence, government incentives to theses high income farmers further accelerate the income gap among the farming community, signaling inappropriate subsidy program of government.

There are $38.4 \%$ of households and $44.7 \%$ population from farmer community having below USD \$5 (RM 6,387 annually) per capita income, and 65.7\% of the households and $72.8 \%$ of the population are below USD \$10 (RM 12,775 annually) per capita income (Table 24). Currently, the target of IADA is to ensure RM 2000 monthly (RM 24000 or USD \$6857 annually) income only from paddy production for each farmer. Assuming only one farmer in each household, $44 \%$ of households are currently below this level. So, substantial increase in income is needed to reach the level.

However, projection shows that any variation of rainfall more than $0.4 \%$ by the year 2020 will cause reduction in farmers' earnings further (NRS 2001). This projection of drop in farmers' income due to changes in rainfall is alarming.

\section{Insert Table 2 about here}

\section{Changes in the Source of Agricultural Income}

The IADA area is allowed only for paddy production where paddy provides $90.3 \%$ of agriculture related income of the farmers. Moreover, one third of the farmers have income from permanent plants such as, mango, coconut, palm oil, cocoa, banana etc., which is alarming because these lands are not anymore suitable for cultivating paddy. IADA officials are mostly trying to check these permanent plants, but farmers' tendency is to shift these plants for crops other than paddy. These permanent plants provide $7 \%$ of agricultural income of the farmers, which is found to be maximum $63.7 \%$ for individual case.

With the paddy production, farmers also like to produce seasonal crops, seasonal fruits and seasonal vegetables which are also prone to climate change. Only 3\% of the farmers produce these crops, and maximum of $7.6 \%$ agricultural income comes from this area. Livestock also provides very small portion of total agricultural income of paddy producing farmers. Only $6.6 \%$ of the farmers are engaged in livestock productions that may provide maximum of $27.9 \%$ of total agricultural income.

Agricultural wages constitute another important source of agricultural income where $14.6 \%$ of the farmers are engaged in. It provides $2.1 \%$ of average agricultural income of the farmers that accounts for a maximum of $35.7 \%$ of individual income from agriculture.

\section{Changes in the Sources of Household Income}

The household income of farmers should arguably be more from farming activities because their main income source is agriculture. If the non-agricultural income or other incomes are more than agricultural income, the attention towards farming decreases and agriculture may gradually shift from main to secondary occupation. Among the farmers, agricultural income of $10.6 \%$ of the households is less than their non-agricultural or other incomes. Moreover, $41.4 \%$ have incomes from outside of agricultural sources, which are found maximum $97.7 \%$ for individual case. On an average, $14.3 \%$ income of paddy farming household come from 
non-agricultural income, such as non-agricultural wage or business income, and other incomes, such as spouse income, children income, pension, welfare, land rent, other rent, savings or investment return-dividend, interest, share market return, trust fund return, insurance, etc.

\section{Changes in Poverty Intensity}

Among the farmers, only $2.1 \%$ live below $\$ 1$ dollar poverty line, and $8.2 \%$ live below $\$ 2$ dollar poverty line. According to Malaysian poverty line, $3.5 \%$ of households and $3.7 \%$ of the populations from farming communities live below poverty line. As this group of farmers is under high subsidized and more productive paddy growing area, here income level of farmers is higher than outside of IADA area. Without the subsidy, the actual poverty rate goes higher. Moreover if the subsidy is not increasing continuously, this poverty rate will increase further. So, the vulnerability in terms of income and poverty is increasing more due to the change of agricultural productivity and profitability.

\section{Changes in the Profession and Agricultural Involvement}

Farmers' active involvement in agriculture is declining due to climate change. As mentioned earlier, currently, $18.7 \%$ of the farmers do not prefer agriculture, and $17.2 \%$ are engaged in agriculture on part time basis (Table 3). However, only 18.7\% said that full time engagement in agriculture is more profitable than part time engagement, and $56.6 \%$ support part time engagement for more returns (Table 3). This indicates, many farmers are trying to reduce their involvement in agriculture from full time engagement to part time workers and thus searching for other sources of income.

\section{Insert Table 3 about here}

Farmers are engaged in agriculture because most of them $(51.5 \%)$ have no alternative job except cultivation (Table 4). $25.3 \%$ of the farmers are engaged here due to social status that they feel it is traditional and respected job, but within this group $24 \%$ are not strongly passionate about agriculture, but prefer trade or other job. Among the farmers, $17.2 \%$ are engaged in agriculture on part time basis. As they have alternative occupation, $61.7 \%$ of them are not passionate for agriculture. $6.1 \%$ of the farmers are engaged in agriculture for other reasons and $33.3 \%$ of them do not prefer to be engaged in agriculture. A total of $18.7 \%$ of current farmers do not prefer agriculture, but $10.1 \%$ prefer other jobs and $8.6 \%$ prefer trading.

\section{Insert Table 4 about here}

\section{Changes in the Stability of Economic Position}

Among all the farmers, $56.6 \%$ have no current savings, who are in high vulnerable group. About $80 \%$ of households have no savings except the savings of heads of the household who are also in high risk group. The most vulnerable groups are those who have no household savings leaving nil per capita savings. So, any type of spike in regular life due to the natural disaster, disease, crime or social issues will push them towards borrowings. Moreover, household savings of $3.5 \%$ and per capita savings of $12.1 \%$ population are below RM 500, who are fairly risky group. 
According to farmers, $73.7 \%$ mentioned about having health problems due to climate change. Climate change has many negative impacts on human health, because a wide range of diseases - vector-borne, water-borne and respiratory - have links to climatic changes. Climatic factors are directly connected to incidences of diarrhea, skin disease, malaria, kalaazar, dengue fever and other illnesses. Other health-related factors, such as dehydration, malnutrition, and heat stress, especially among elder farmers, are closely linked to climate factors and food production.

\section{REQUIREMENTS FOR SOCIOECONOMIC ADAPTATION}

Among the financial and relevant socioeconomic supports from government, raw materials subsidy and cash incentive were found necessary and needed for $79.8 \%$ of the farmers to cope with climate change impacts (Table 5). Among those who needed raw materials subsidy $54 \%$ of farmers emphasized it as very important, and among those who need cash incentive $47 \%$ mention it was very important to cope with climate change. $78.3 \%$ emphasized on insurance supports or minimum income ensuring supports to adapt to climate change. $78.8 \%$ of the farmers agreed about the necessity of infrastructure related supports such as transportation and irrigation.

\section{Insert Table 5 about here}

The highest number of the farmers $(80.8 \%)$ emphasized on the importance of proper guidelines and suggestions to adapt to climate change properly. $71.7 \%$ emphasized on importance of land usage pattern to cope with climate change. $73.2 \%$ of the farmers mentioned that the leasing system and agricultural wage were important factors toward adaptation to climate change. To adapt to climate change, $71.2 \%$ of the farmers thought merger of individual farmers into single, large farms was necessary.

\section{POLICY RECOMMENDATIONS}

To ensure the sustainability of agriculture and relevant human livelihood in the long run, adaptation is essential. Adaptation to climate change is a broad issue. Several recent studies focus on climatic adaptation, especially in the agricultural sector both in Malaysia and abroad, such as Ferdous et al. 2015, Ahmed et al. 2015, Nazneen et al. 2015, Masud et al. 2015, 2014, Hamdan et al. 2014, 2013, Devendra 2012, Salvo et al. 2013, Gebrehiwot and Van Der Veen 2013. It needs to be undertaken at many levels, including at the household and community levels. Many of these initiatives are self-funded (Stern 2007). Government also needs to take proper financial supports for socioeconomic stability, technological innovation, and infrastructural development as well as conducting several skill development programs to the farmers. Several relative studies discussed the issue of currently available supports from government for adaptability of the farmers, and required new supports for future adaptability of farmers, and also suggest a guideline to consider for adaptation policy in Malaysia (Alam et al. 2012). Current government incentive and subsidy policy are not appropriate and also inadequate. Here, government's subsidy supports and incentive programs need to define strategically that it will influence yield productivity and ensure socioeconomic sustainability without increasing inequality. Other relevant factors, such as agricultural wage, land leasing system and rate, maximum farm size, etc. need much attention (Alam et al. 2012). These factors are very important for sustainability of small farmers, poverty reduction and reduce income inequality (Alam et al. 2010b, 2011). Government's attention to these factors will help increase overall productivity to gain self-sufficiency, or close to self-sufficiency, and to 
ensure food security. Government's supports for technological adaptation to climate change are very important to deal with the climatic problems in the long run.

It is apparent that development of technology is a boundless area, but it is possible in several ways. The most efficient method of technological advancement is expected to be able to solve the problem by controlling the climate factors. China showed an example of how to create rainfall by gun firing in the sky and also protect rainfall. Until gaining such level of technological advancement in all aspects, there should be some phases of development which are expected to help the agricultural farmers in their effort to adapt to climate changes. Thus, technology needs to be developed in different stages and ways such as to improve shielding resources such as, protect crops from excessive rainfall, solve water login problems, or to develop defensive approach such as, verities of crops development, rainfall and temperature tolerant plants, or to find alternative approach such as, changing crop cycle, reduce the timing of crop cycle.

Farmers also need to take trainings to become used to the usage of basic technology. The production practices of farm and the knowledge of individual farmer also need to be updated with the changes of climate factors. The agricultural farmers should understand the crop rotation, crop portfolio, crop substitutions and technological exchange knowledge sharing for sustainable food production (Alam et al. 2012). They should also take all precautions and be aware about the uncertainty of low rainfall and heavy rainfall. They must be careful in arranging proper water management, both in terms of irrigation facilities and quick water logout facilities etc. On the basis of several requirements of farmers, however, the IADA authorities in North West Selangor also need to engage different new groups of stakeholders to ensure necessary facilities, especially technological, insurance, training supports for agricultural adaptation to climate change vulnerabilities.

The financial management of farms and farmers too needs to be secured for a minimum of two seasons so that if crop is damaged in one season, they will be prepared and have the seeds for next season; their ability to bear the cost of another crop production will guarantee their survival financially up to the collection of the new crops. Currently heavy rainfall and storm is a very common phenomenon in the study area. For that reason, farmers should take the initiative for crop sharing, forward rating, hedging and insurance. Farmers also need crop insurance facilities, but no such option is currently available. Moreover, they need to take income stabilization programs, such as portfolio of investment, saving scheme, minimum income protection by government or insurance to reduce the risk of income loss due to changing climatic conditions and variability.

Finally, as climate change is not particularly related to any community, everyone needs to be informed about its impacts and they should also be encouraged to think about its possible adaptation approaches. Due to social interaction, the socioeconomic variables of any community have strong linkages, interactions and influences of other community, and for any national or common issue all social groups are interconnected and, more or less, affected. So, everyone in the society needs to build up a mind set about the warming climate, and what needs to be done. At the same time, people, particularly those in the richer groups, need to explore the best ways to build low-carbon economies in spite of their luxurious and overconsumption patterns of lifestyle. This will help to curb the socioeconomic vulnerability of any particular groups in the society, and enable everyone in similar types of mentality to cope with the adverse effects of climate change. At last, the study suggests preparing a 
planned and proactive adaptation strategy in Malaysia to secure sound functioning of the economic, social and agricultural system.

\section{CONCLUSIONS}

Like in many other countries, changes in climatic factors have negative impacts on productivity of paddy cultivation in the study area. Projections of climatic change and its adverse effects on paddy productivity and socioeconomic status of the farmers have been found alarming. Majority of the farmers strongly perceive that climatic changes have caused profitability of paddy cultivation to decline. Many farmers are trying to reduce their involvement with agriculture. As a result, $56.6 \%$ are inclined to prefer part-time to full-time engagement in paddy cultivation. A Kuznets ratio of 2.88 and the Gini coefficient of 0.443 suggest that there is a high level of income inequality among the paddy farmers in the study area.

Among the paddy producing farmers, $68.2 \%$ agree that paddy production is not much profitable due to low productivity. However, $67.2 \%$ of farmers feel that because of heavy government subsidies and incentives, paddy cultivation is still better and more profitable than production of other crops. To sustain this profitability, there is no alternative to increase the productivity and growth of the sector.

\section{ACKNOWLEDGEMENT}

We are thankful to Ministry of Science, Technology and Environment of the Government of Malaysia for generously funding the research, under the Research University Grant (UKMGUP-PI-08-34-081). We would also like to thank Prof. Chamhuri Siwar, Prof. Mohd Ekhwan bin Toriman, Dr. Basri Talib, Prof. Rafiqul Islam Molla, Dr. Wahid Murad, and Keith Alverson for their advices and supports at various stages of the study.

\section{REFERENCES}

Adger WN (1999) Social vulnerability to climate change and extremes in coastal Vietnam. World Development, Vol. 27(2), pp. 249-269.

Agriculture Statistical Handbook (2008) Paddy. Ministry of Agriculture. Malaysia.

Ahmed A, Masud M, Al-Amin AQ, Rohani S, Rahman M, Rulia A (2015) Exploring Factors Influencing Farmers' Willingness to Pay (WTP) for a planned adaptation program to address climatic issues in agricultural sectors. Environmental Science and Pollution Research, Vol. 22, pp. 9494-9504.

Alam MM, Siwar C, Molla RI, Toriman ME, Talib B (2011) Climate change and vulnerability of paddy cultivation in North-West Selangor, Malaysia: a survey of farmers' assessment. Voice of Academia, Vol. 6(1), pp. 45-56.

Alam MM, Siwar C, Molla RI, Toriman ME, Talib B. (2010b) Socioeconomic impacts of climatic change on paddy cultivation: an empirical investigation in Malaysia Journal of Knowledge Globalization, Vol. 3(2), pp. 71-84. http://journals.sfu.ca/jkg/index.php/journal/article/view/57/44. Accessed 05 Nov 2015

Alam MM, Siwar C, Toriman ME (2010a) Socioeconomic Study of Climate Change: An Assessment of Agriculture and Livelihood Sustainability on Paddy Farming in Malaysia. LAP Lambert Acad. Saarbrucken.

Alam MM, Siwar, C, Molla RI, Talib B, Toriman ME (2012) Paddy farmers' adaptation practices to climatic vulnerabilities in Malaysia, Mitigation and Adaptation Strategies 
for Global Change, Vol. 17(4), pp. 415-423. DOI: 10.1007/s11027-011-9333-7. Accessed 05 Nov 2015

Alam, MM, Siwar, C, Talib, B, and Mohd Ekhwan, T (2014) Impacts of Climatic Changes on Paddy Production in Malaysia: Micro Study on IADA at North West Selangor, Research Journal of Environmental and Earth Sciences, Vol. 6(5), pp. 251-258. http://www.maxwellsci.com/jp/abstract.php?jid=RJEES\&no=438\&abs=02. Accessed 05 Nov 2015

Baker JT, Allen JrLH (1993) Contrasting crop species responses to $\mathrm{CO}_{2}$ and temperature: rice, soybean and citrus. Vegetatio, Vol. 104/105, pp. 239-260. http://www.jstor.org/pss/20029749. Accessed 05 Nov 2015

Daly H, Cobb J (1990) For the Common Good. Green Print Publishing: London. Department for Policy Coordination and Sustainable Development, New York.

Devendra, C (2012) Climate Change Threats and Effects: Changes for Agriculture and Food Security. Malaysia. Negara: Academy of Sciences Malaysia. http://agrilinks.org/sites/default/files/resource/files/climate_change_threats_effects_st rategies.pdf Accessed 05 Nov 2014

Ferdous A, Al-Amin AQ, Masud M, Kari F, Mohamad Z (2015) Science Framework (SF) for Agricultural Sustainability. Anais da Academia Brasileira de Ciências, Vol. 87(3), pp. 1887-1902.

Gebrehiwot T, Van Der Veen A (2013). Farm level adaptation to climate change: The case of farmers in the Ethiopian highlands, Environmental Management, Vol. 52(1), pp. 2944.

Hamdan ME, Man N, Yassin SM, D’Silva JL, Shaffril HAM (2014) Farmers Sensitivity Towards the Changing Climate in the Cameron Highlands. Agricultural Journal, 9: 120-126. http://docsdrive.com/pdfs/medwelljournals/aj/2014/120-126.pdf Accessed 05 Nov 2014

Hamdan, ME, Man N, Yassin SM, D'Silva JL, Shaffril HAM (2013) Farmers' adaptive capacity towards the impacts of global warming : a review. Asian Social Science, 9 (13).

pp.

177-184. http://ccsenet.org/journal/index.php/ass/article/viewFile/30815/18148 Accessed 05 Nov 2014

Homer-Dixon, T (1992) Environment al change and acute conflict. International Security, Vol. 16 (2), pp. 31-102.

IADA (Integrated Agricultural Development Area) (2009) Internal Unpublished Data from the record of North West Selangor, Malaysia, March.

Klein RJT, Schipper ELF, Dessai S (2005) Integrating mitigation and adaptation into climate and development policy: three research questions. Environmental Science and Policy, Vol. 8(6), pp. 579-588.

Liebman B (2007) Malaysia leads the world in greenhouse gas emission growth rate. Curb $\begin{array}{lll}\text { Global Warm. Nov } & 29 .\end{array}$ http://curbglobalwarmingblog.blogspot.com/2007/11/malaysia-leads-world-ingreenhouse-gas.html Accessed 05 Nov 2015

Masud M, Rahman S, Al-Amin AQ, Fatimah K, Leal W (2014) Impact of Climate Change: An empirical investigation of Malaysian rice production. Mitigation and Adaptation of Strategies for Global Change, Vol. 19, pp.431-444.

Masud MM, Junsheng H, Akhtar R, Al-Amin AQ, Kari F (2015) Estimating Farmers' Willingness to Pay for Climate Change Adaptation: the case of the Malaysian Agricultural Sector, Environmental Monitoring and Assessment. Vol. 187(38), pp.112. 
NAHRIM (2006) Final Report: Study of the Impact of Climate Change on the hydrologic Regime and Water Resources of Peninsular Malaysia, National Hydraulic Research Institute of Malaysia (NAHRIM) and California Hydrologic Research Laboratory (CHRL), $\quad$ Malaysia. http://www.nahrim.gov.my/download/pksa/RegHCM_PM_Report_9_21_06_Ex\%20v 1.pdf. Accessed 05 Nov 2015

Nazneen J, Al-Amin AQ, Fatimah K, Alam M (2015) Climate change adaptation provisions for the agricultural sector in Malaysia. International journal of global warming. Vol. 7(3), pp. 336-347.

NRS (2001) National Response Strategies to Climate Change. Ministry of Science, Technology and the Environment, Malaysia. http://gedung.nahrim.gov.my/wapi/mctweb.dll/getObject?MID=WATER\%20RESOU RCES\&Sn=2038. Accessed 05 Nov 2015

Reilly J (1999) Climate change: can agriculture adapt? Choices, Vol. 14(1), pp. 4-8.

Salvo MD, Begalli D, Signorello G (2013) Measuring the effect of climate change on agriculture: A literature review of analytical models. Journal of Development and Agricultural Economics. Vol. 5(12), pp. 499-509. http://www.academicjournals.org/article/article1384267016_Salvo\%20et\%20al.pdf Accessed 05 Nov 2014

Schimmelpfenning D (1996) Uncertainty in economic models of climate change impacts. Climatic Change, Vol. 33(2), pp. 213-34.

Singh S, Amartalingam R, Wan Harun WS, Islam MT (1996) Simulated impact of climate change on rice production in Peninsular Malaysia. Proceeding of National Conference on Climate Change. pp. 41-49, UPM, Malaysia.

Siwar C, Alam MM, Murad MW, Al-Amin AQ (2009) A review of the linkages between climate change, agricultural sustainability and poverty in Malaysia. International Review of Business Research Papers, Vol. 5(6), pp. 309-321. http://www.bizresearchpapers.com/23.\%20Siwar.pdf. Accessed 05 Nov 2015

Smit, B, Skinner, MW (2002) Adaptation options in agriculture to climate change: a typology. Mitigation and Adaptation Strategies for Global Change, Vol. 7, pp. 85114.

Stern, N (2007) The Economics of Climate Change: The Stern Review. Cambridge University Press, Cambridge

Tashiro T, Wardlaw IF (1989) A comparison of the effect of high temperature on grain development in wheat and rice. Annals of Botany, Vol. 64, pp. 59-65. http://aob.oxfordjournals.org/content/64/1/59.full.pdf. Accessed 05 Nov 2015

The Associated Press (2007) Malaysian Growth of Carbon Emissions Highest in the World, UN Says. The Irrawaddy. Nov 29. http://www.irrawaddy.org/article.php?art_id=9454. Accessed 05 Nov 2015

Tisdell C (1996) Economic indicators to assess the sustainability of conservation farming projects: an evaluation. Agriculture, Ecosystems and Environment, Vol. 57(2), pp. 117-131. $\quad$ http://www.sciencedirect.com/science/article/pii/0167880996010171. Accessed 05 Nov 2015

United Nations (1997) Critical Trends: Global Changes and Sustainable Development. UN 


\section{APPENDIX}

Table 1: Projection of Revenue Changes (RM/ Ha) for Paddy Production in 2020 with Variations of Temperature and Rainfall at Certain Level of $\mathrm{CO}_{2}$

\begin{tabular}{cccc}
\hline \multirow{2}{*}{ Variation in Rainfall } & \multicolumn{4}{c}{ Variation in Temperature $\left({ }^{0} \mathrm{C}\right)$} \\
\cline { 2 - 4 } $\mathbf{1 4 \%}$ & -554.2 & $\mathbf{0 . 8 5}$ & $\mathbf{1 . 4}$ \\
$\mathbf{7 \%}$ & -291.8 & -554.2 & -554.2 \\
$\mathbf{0 . 4 \%}$ & 0 & -291.8 & -291.8 \\
$\mathbf{0 \%}$ & 0 & 0 & 0 \\
$\mathbf{- 0 . 4 \%}$ & 0 & 0 & 0 \\
$\mathbf{- 7 \%}$ & -264.5 & 0 & 0 \\
$\mathbf{- 1 4 \%}$ & -529.0 & -251.9 & -224.0 \\
* Revenue calculated as paddy price per & -504.3 & -488.0 \\
Normal Grade @ RM51.69 & &
\end{tabular}

Source: NRS 2001

Table 2: Projection of Earning Changes (RM) for Paddy Production with Different Variations of Temperature and Rainfall

\begin{tabular}{|c|c|c|c|c|c|c|c|c|c|c|c|}
\hline \multicolumn{4}{|c|}{ Year 2020} & \multicolumn{4}{|c|}{ Year 2040} & \multicolumn{4}{|c|}{ Year 2060} \\
\hline $\begin{array}{l}\mathbf{C O}_{2} \\
(\mathrm{ppm})\end{array}$ & 400 & 400 & 400 & $\begin{array}{l}\mathbf{C O}_{2} \\
(\mathrm{ppm})\end{array}$ & 600 & 600 & 600 & $\begin{array}{l}\mathbf{C O}_{2} \\
(\mathrm{ppm})\end{array}$ & 800 & 800 & 800 \\
\hline $\mathbf{V}_{\text {temp( }}\left(^{o} \mathrm{C}\right)$ & 0.3 & 0.85 & 1.4 & $\left.\mathbf{V}_{\text {temp( }}{ }^{o} \mathrm{C}\right)$ & 0.4 & 1.4 & 2.4 & $\mathbf{V}_{\text {temp }}\left({ }^{o} \mathrm{C}\right)$ & 0.6 & 2 & 3.4 \\
\hline $\mathbf{V}_{\text {rainfall }}$ & & & & $\mathbf{V}_{\text {rainfall }}$ & & & & $\mathbf{V}_{\text {rainfall }}$ & & & \\
\hline $14 \%$ & -554.2 & -554.2 & -554.2 & $23 \%$ & -892.1 & -892.1 & -892.1 & $32 \%$ & $-1,229.5$ & $-1,229.5$ & $-1,229.5$ \\
\hline $7 \%$ & -291.8 & -291.8 & -291.8 & $11 \%$ & -441.9 & -441.9 & -441.9 & $15 \%$ & -591.9 & -591.9 & -591.9 \\
\hline $0.40 \%$ & 0 & 0 & 0 & $0.70 \%$ & 0 & 0 & 0 & $1 \%$ & 0 & 0 & 0 \\
\hline $0 \%$ & 0 & 0 & 0 & $0 \%$ & 0 & 0 & 0 & $0 \%$ & 0 & 0 & 0 \\
\hline $0.40 \%$ & 0 & 0 & 0 & $-0.70 \%$ & 0 & 0 & 0 & $-1 \%$ & 0 & 0 & 0 \\
\hline$-7 \%$ & -264.5 & -251.9 & -224.0 & $-11 \%$ & -522.1 & -499.1 & -476.0 & $-15 \%$ & -862.7 & -818.6 & -774.5 \\
\hline$-14 \%$ & -529.0 & -504.3 & -488.0 & $-23 \%$ & -1091.5 & -1043.2 & -994.9 & $-32 \%$ & $-1,840.8$ & $-1,764.9$ & $-1,652.4$ \\
\hline
\end{tabular}

* Earning calculates as paddy price per 100kg Super Grade= RM55.00 \& Normal Grade= RM51.69

Source: NRS 2001

Table 3: Profitability of Involvement with Agriculture

\begin{tabular}{|c|c|c|c|c|c|c|c|c|c|}
\hline \multirow{2}{*}{ Statement } & \multicolumn{5}{|c|}{ Observation Scale* } & \multirow{2}{*}{$\begin{array}{l}\text { Average } \\
\text { Value of } \\
\text { Scale }\end{array}$} & \multirow{2}{*}{ S.D. } & \multirow{2}{*}{$\begin{array}{c}\text { Agreed } \\
(4 \text { \& 5) } \\
\text { Observation }\end{array}$} & \multirow{2}{*}{$\begin{array}{l}\text { Disagreed } \\
\quad(1 \text { \& 2) } \\
\text { Observation }\end{array}$} \\
\hline & 1 & 2 & 3 & 4 & 5 & & & & \\
\hline $\begin{array}{l}\text { Part time work } \\
\text { in Agriculture is } \\
\text { more profitable } \\
\text { than full time }\end{array}$ & $\begin{array}{r}24 \\
12.1 \%\end{array}$ & $\begin{array}{r}13 \\
6.6 \%\end{array}$ & $\begin{array}{r}49 \\
24.7 \%\end{array}$ & $\begin{array}{r}85 \\
42.9 \%\end{array}$ & $\begin{array}{r}27 \\
13.6 \%\end{array}$ & 3.39 & 1.17 & $\begin{array}{r}112 \\
56.6 \%\end{array}$ & $\begin{array}{r}37 \\
18.7 \%\end{array}$ \\
\hline
\end{tabular}

*Scale: 1 = Strongly Disagree, 2 = Disagree, 3 = No Comment, 4 = Agree, 5 = Strongly Agree 
Table 4: Preferred Activities of Farmers and Reasons of Engagement in Agriculture

\begin{tabular}{|c|c|c|c|c|c|c|}
\hline \multirow[b]{2}{*}{ Prefer Activities } & \multicolumn{4}{|c|}{ Reason to Engaged in Agriculture Rather than Wages Job } & \multirow[b]{2}{*}{ Total } & \multirow[b]{2}{*}{$\%$ of Total } \\
\hline & No Alternative job & Social Status & $\begin{array}{c}\text { Part time } \\
\text { Engagement } \\
\end{array}$ & Other & & \\
\hline Cultivation & 102 & 38 & 13 & 8 & 161 & $81.30 \%$ \\
\hline Trade & & 7 & 9 & 1 & 17 & $8.60 \%$ \\
\hline Wage job & & 5 & 12 & 3 & 20 & $10.10 \%$ \\
\hline Total & 102 & 50 & 34 & 12 & 198 & $100 \%$ \\
\hline$\%$ of Total & $51.50 \%$ & $25.30 \%$ & $17.20 \%$ & $6.10 \%$ & $100 \%$ & \\
\hline
\end{tabular}

Table 5: Socioeconomic Issues Relevant Required Supports for Adaptation to Climate Change

\begin{tabular}{|c|c|c|c|c|c|c|c|c|c|}
\hline \multirow{2}{*}{$\begin{array}{l}\text { Types of } \\
\text { Supports }\end{array}$} & \multicolumn{5}{|c|}{ Observation Scale* } & \multirow{2}{*}{$\begin{array}{c}\text { Average } \\
\text { Value } \\
\text { of Scale }\end{array}$} & \multirow{2}{*}{ S.D. } & \multirow{2}{*}{$\begin{array}{c}\text { Agreed } \\
(4 \text { \& 5) } \\
\text { Observation }\end{array}$} & \multirow{2}{*}{$\begin{array}{l}\text { Disagreed } \\
\quad(1 \text { \& 2) } \\
\text { Observation }\end{array}$} \\
\hline & 1 & 2 & 3 & 4 & 5 & & & & \\
\hline Raw materials subsidy & $\begin{array}{r}5 \\
2.5 \%\end{array}$ & $\begin{array}{r}10 \\
5.1 \%\end{array}$ & $\begin{array}{r}25 \\
12.6 \%\end{array}$ & $\begin{array}{r}51 \\
25.8 \%\end{array}$ & $\begin{array}{r}107 \\
54 \%\end{array}$ & 4.24 & 1.02 & $\begin{array}{r}158 \\
79.8 \%\end{array}$ & $\begin{array}{r}15 \\
7.6 \%\end{array}$ \\
\hline Cash Incentive & $\begin{array}{r}7 \\
3.5 \%\end{array}$ & $\begin{array}{r}8 \\
4 \%\end{array}$ & $\begin{array}{r}25 \\
12.6 \%\end{array}$ & $\begin{array}{r}65 \\
32.8 \%\end{array}$ & $\begin{array}{r}93 \\
47 \%\end{array}$ & 4.16 & 1.03 & $\begin{array}{r}158 \\
79.8 \%\end{array}$ & $\begin{array}{r}15 \\
7.6 \%\end{array}$ \\
\hline Insurance Support & $\begin{array}{r}7 \\
3.5 \%\end{array}$ & $\begin{array}{r}1 \\
0.5 \%\end{array}$ & $\begin{array}{r}35 \\
17.7 \%\end{array}$ & $\begin{array}{r}83 \\
41.9 \%\end{array}$ & $\begin{array}{r}72 \\
36.4 \%\end{array}$ & 4.07 & 0.94 & $\begin{array}{r}155 \\
78.3 \%\end{array}$ & $\begin{array}{r}8 \\
4 \%\end{array}$ \\
\hline $\begin{array}{l}\text { Infrastructural } \\
\text { Support, such as } \\
\text { Irrigation, } \\
\text { Transportation }\end{array}$ & $\begin{array}{r}7 \\
3.5 \%\end{array}$ & $\begin{array}{r}5 \\
2.5 \%\end{array}$ & $\begin{array}{r}30 \\
15.2 \%\end{array}$ & $\begin{array}{r}43 \\
21.7 \%\end{array}$ & $\begin{array}{r}113 \\
57.1 \%\end{array}$ & 4.26 & 1.04 & $\begin{array}{r}156 \\
78.8 \%\end{array}$ & $\begin{array}{r}12 \\
6.1 \%\end{array}$ \\
\hline $\begin{array}{l}\text { Proper Guidelines or } \\
\text { Suggestion }\end{array}$ & $\begin{array}{r}6 \\
3 \%\end{array}$ & $\begin{array}{r}3 \\
1.5 \%\end{array}$ & $\begin{array}{r}29 \\
14.6 \%\end{array}$ & $\begin{array}{r}70 \\
35.4 \%\end{array}$ & $\begin{array}{r}90 \\
45.5 \%\end{array}$ & 4.19 & 0.95 & $\begin{array}{r}160 \\
80.8 \%\end{array}$ & $\begin{array}{r}9 \\
4.5 \%\end{array}$ \\
\hline $\begin{array}{l}\text { Adjustment in Land } \\
\text { Use Pattern }\end{array}$ & $\begin{array}{r}5 \\
2.5 \%\end{array}$ & $\begin{array}{r}6 \\
3 \%\end{array}$ & $\begin{array}{r}45 \\
22.7 \%\end{array}$ & $\begin{array}{r}63 \\
31.8 \%\end{array}$ & $\begin{array}{r}79 \\
39.9 \%\end{array}$ & 4.04 & 0.99 & $\begin{array}{r}142 \\
71.7 \%\end{array}$ & $\begin{array}{r}11 \\
5.6 \%\end{array}$ \\
\hline $\begin{array}{l}\text { Adjustment in Wage } \\
\text { and Leasing System }\end{array}$ & $\begin{array}{r}7 \\
3.5 \%\end{array}$ & $\begin{array}{r}9 \\
4.5 \%\end{array}$ & $\begin{array}{r}37 \\
18.7 \%\end{array}$ & $\begin{array}{r}46 \\
23.2 \%\end{array}$ & $\begin{array}{r}99 \\
50 \%\end{array}$ & 4.12 & 1.09 & $\begin{array}{r}145 \\
73.2 \%\end{array}$ & $\begin{array}{r}16 \\
8.1 \%\end{array}$ \\
\hline $\begin{array}{l}\text { Merge Individual } \\
\text { Farmers to Farm }\end{array}$ & $\begin{array}{r}7 \\
3.5 \%\end{array}$ & $\begin{array}{r}17 \\
8.6 \%\end{array}$ & $\begin{array}{r}33 \\
16.7 \%\end{array}$ & $\begin{array}{r}70 \\
35.4 \%\end{array}$ & $\begin{array}{r}71 \\
35.9 \%\end{array}$ & 3.91 & 1.09 & $\begin{array}{r}141 \\
71.2 \%\end{array}$ & $\begin{array}{r}24 \\
12.1 \%\end{array}$ \\
\hline
\end{tabular}

*Scale: 1 = Strongly Not Needed, 2 = Not Needed, 3 = Not Sure, 4 = Needed, 5 = Strongly Needed 


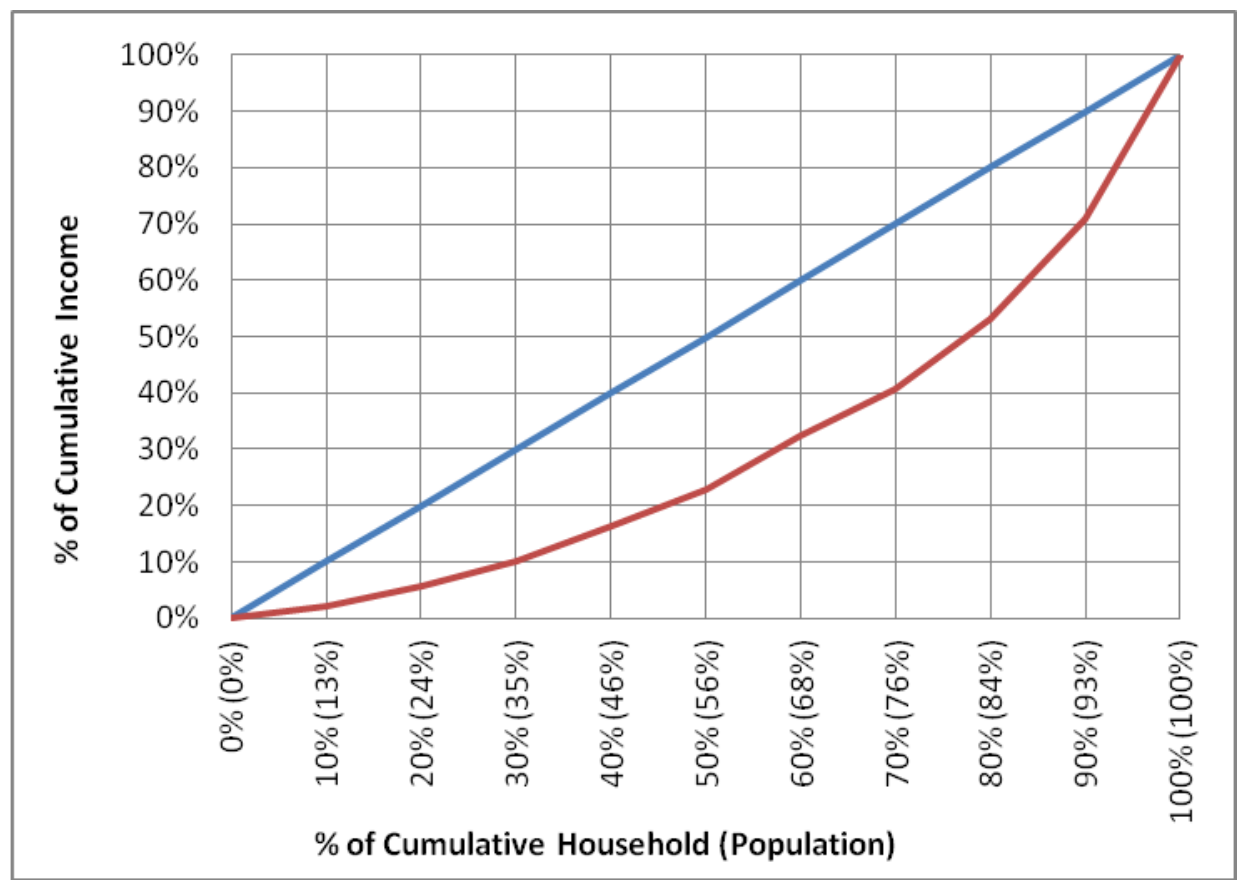

Figure 1: Lorenz Curve or Income Inequality among Farmers 